\title{
BAURAN PEMASARAN JASA SEBAGAI PEMICU KEPUTUSAN NASABAH MEMILIH PRODUK BANK SYARIAH
}

\author{
Jamilah Iriany Nur ${ }^{1}$, Agussalim Harrang ${ }^{2}$ \\ ${ }^{1}$ Mahasiswa Prodi Hukum Ekonomi Syariah FAI Unismuh Makassar \\ ${ }^{2}$ Dosen Prodi Ekonomi Islam FEBIS Unismuh Makassar
}

\begin{abstract}
Abstrak
Jenis penelitian ini merupakan penelitian kuantitatif yang dilakukan di PT. Bank Sulselbar.Penelitian ini termasuk penelitian kuantitatif yang bertujuan untuk mengetahui dan menganalisis bauran pemasaran jasa terhadap keputusan nasabah memilih produk Bank Syariah pada PT. Bank Sulselbar Kantor Cabang Syariah Makassar. Dalam penelitian ini terdiri dari tiga variabel, yaitu Bauran Pemasaran( $\beta$ ), PT. Bank Sulselbar Syariah $(\gamma)$, dan Keputusan Nasabah $(\delta)$.

Total Sampling dalam penelitian ini berjumlah 65 nasabah. Untuk gambaran Pengaruh Bauran Pemasaran Jasa Terhadap Keputusan Nasabah Memilih Produk Bank Syariah peneliti menggunakan skala kepribadian, lembar observasi dan wawancara bebas pada nasabah PT. Bank Sulselbar Kantor Cabang Syariah Makassar. Selanjutnya, data yang diperoleh melalui instrument tersebut kemudian diolah melalui analisis regresi linear berganda dengan bantuan aplikasi XLSTAT (PLS- PM) .
\end{abstract}

Hasil penelitian menunjukkan bahwa hasil analisis inferensial yang menggunakan uji t dengan rumus regresi linear berganda menunjukkan bahwa nilai t hitung lebih besar dari pada nilai t table. Artinya bauran pemasaran jasa kurang mempengaruhi keputusan nasabah pada PT. Bank Sulselbar Kantor Cabang Syariah Makassar.

Kata Kunci: Keputusan Nasabah.

\section{Abstract}

This type of research is a quantitative research conducted at PT. Bank Sulselbar. This research includes quantitative research which aims to know and analyze the service marketing mix to customer decision to choose the product of Bank Syariah at PT. Bank Sulselbar Makassar Sharia Branch Office. In this study consists of three variables, namely Marketing Mix ( $\beta), P T$. Bank Sulselbar Syariah ( $($ ), and Customer Decision (ס).

Total Sampling in this study amounted to 65 customers. To illustrate the Influence of Marketing Service Mix on Customer Decision Selecting Bank Syariah Product Researcher using personality scale, observation sheet and free interview on customer PT. Bank Sulselbar Makassar Sharia Branch Office. Furthermore, the data obtained through the instrument is then processed through multiple linear regression analysis with the help of XLSTAT application (PLSPM).

The results showed that the results of inferential analysis using $t$ test with multiple linear regression formula shows that the value of $t$ arithmetic greater than the value of $t$ table. This means that the marketing mix of services less influence customer decisions at PT. Bank Sulselbar Makassar Sharia Branch Office.

Keywords: Customer Decision. 


\section{A. PENDAHULUAN}

Maraknya perbankan syariah bukan merupakan gejala baru dalam dunia bisnis syariah. Keadaan ini ditandai dengan semangat tinggi dari berbagai kalangan, yaitu: ulama, akademisi, dan praktisi untuk mengembangkan perbankan tersebut. Menurut beberapa penelitian yang telah dilakuakan mengenai bank syariah, khususnya yang berhubungan dengan nasabah bank syariah, yang menjadi alasan mereka untuk mau berhubungan dan menjadi nasabah adalah alasan keagamaan, yang menyatakan bahwa bunga bank yang diterima melalui bank konvensional haram hukumnya dalam syariat islam, sehingga ada keinginan dari para warga muslim untuk membentuk suatu lembaga perbankan yang sesuai dengan syariah islam, yaitu bank syariah ini.

Bauran pemasaran dinilai dapat mempengaruhi pertimbangan konsumen untuk menjadi nasabah bank syariah. Bauran pemasaran (marketing mix) merupakan seperangkat alat pemasaran yang digunakan perusahaan untuk terusmenerus mencapai tujuan pemasaran di pasar sasaran (Kotler, 2008:6).

Permasalahan dalam penelitian ini adalah, variabel PT. Bank Sulselbar
Syariah $(\gamma)$ berpengaruh terhadap variabel Bauran pemasaran $(\beta)$, variabel PT. Bank Sulselbar Syariah $(\gamma)$ berpengaruh terhadap variabel Keputusan Nasabah $(\delta)$, variabel Bauran pemasaran $(\beta)$ berpengaruh terhadap variabel Keputusan Nasabah $(\delta)$.

Kegiatan pemasaran harus dilandasi semangat beribadah kepada Tuhan Sang Maha Pencipta, berusaha semaksimal mungkin untuk kesejahteraan bersama, bukan untuk kepentingan golongan apalagi kepentingan sendiri. Islam menghalalkan umatnya berniaga. Bahkan Rasulullah Shallallahu 'alaihi wa sallam seorang saudagar sangat terpandang pada zamannya. Sejak muda beliau dikenal sebagai pedagang jujur. Kegiatan ekonomi yang dilakukan saling ridho, sebagaimana firman Allah Ta'ala, QS. An-Nisaa: 29

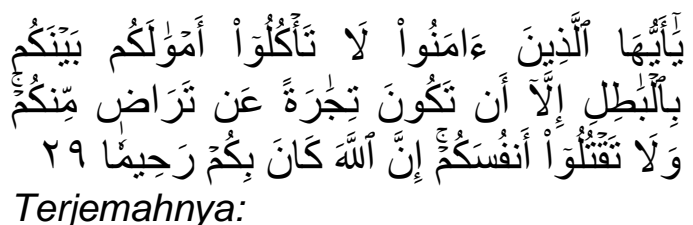

Terjemahnya:

"Hai orang-orang yang beriman, janganlah kamu saling memakan harta sesamu dengan jalan yang bathil, kecuali dengan jalan perniagaan yang berlaku dengan suka sama suka di antara kamu. Dan janganlah kamu membunuh dirimu; sesungguhnya Allah adalah Maha Penyayang kepadamu." 
Pemasaran adalah suatu proses terjadinya hubungan sosial dan manajemen dari individu atau kelompok yang saling bekerja sama untuk memenuhi kebutuhan serta keinginan mereka melalui penciptaan, penawaran dalam bentuk komunikasi maupun iklan, dan pertukaran nilai produk barang dan jasa dengan pihak lain dengan harapan akan memberikan berbagai keuntungan bagi kedua belah pihak yang terlibat di dalam proses tersebut (Anggen, 2012:7).

Bauran pemasaran sebagai alat bagi pengusaha untuk mempengaruhi konsumer agar konsumennya dapat menjadi kenal kemudian menyenangi dan kemudian melakukan transaksi pembelian serta akhirnya konsumen itu menjadi puas (Indriyo, 2008:182).

Strategi pemasaran pada dasarnya adalah suatu rencana yang menyeluruh serta terpadu dan menyatu dibidang pemasaran barang dan jasa. Dengan perkataan lainnya strategi pemasaran itu adalah serangkaian tujuan dan sasaran kebijakan, serta aturan yang memberi arah kepada usaha-usaha pemasaran barang dan jasa. Strategi pemasaran adalah wujud rencana yang terarah dibidang pemasaran, untuk memperoleh suatu hasil yang optimal.
Rencana strategi pemasaran perusahaan adalah suatu rencana pemasaran jangka panjang yang bersifat menyeluruh dan strategis, yang merumuskan berbagai strategi dan program pokok bidang pemasaran perusahaan pada suatu jangka waktu tertentu dalam jangka panjang dimasa depan.

\section{Pengambilan}

keputusan

merupakan proses kognitif yang mempersatukan memori, pemikiran, pemprosesan informasi dan penilaianpenilaian secara evaluatif. Situasi di mana keputusan diambil, mendeterminasi sifat eksak dari proses yang bersangkutan. Proses tersebut mungkin memerlukan waktu berbulanbulan lamanya, dengan suatu seri keputusan-keputusan yang dapat diidentifikasi, yang dibuat pada berbagai tahap proses pengambilan keputusan yang berlangsung.

Proses pengambilan keputusan pembelian berakhir pada tahap perilaku purnabeli dimana nasabah merasakan tingkat kepuasan atau ketidak puasan yang dirasakan akan memengaruhi perilaku berikutnya. Jika konsumen merasa puas, ia akan memperlihatkan peluang yang besar untuk melakukan pembelian ulang atau membeli produk lain pada perusahaan yang sama dimasa mendatang, dan 
cenderung merekomendasikan kepada orang lain. Banyak orang berpendapat bahwa pembeli yang puas merupakan iklan yang terbaik bagi produk.

\section{B. METODE PENELITIAN}

Adapun jenis metode yang digunakan peneliti adalah penelitian kuantitatif. Penelitian ini adalah dihasilkan melalui data-data deskriptif (pemaparan) yang diperoleh dari pengamatan di lapangan dan tidak selalu berbentuk angka-angka.

Populasi adalah keseluruhan obyek penelitian. Populasi dalam penelitian ini adalah nasabah Bank Sulselbar Kantor Cabang Syariah (KCS) Makassar. Penentuan jenis populasi ini didasarkan atas alasan bahwa yang akan diuji, nasabah yang memiliki rekening tabungan di PT. Bank Sulselbar Kantor Cabang Syariah (KCS) Makassar sebanyak 65 nasabah.

Sampel adalah objek yang di telitidandianggapmewakiliseluruhpopul asi. Teknik sampling yang digunakan adalah total sampling merupakan teknik pengambilan sampel secara keseluruhan dari jumlah populasi. Jumlah sampel sebanyak 65 nasabah. penarikan sampel didasari kriteria yaitu : 1) Nasabah memiliki rekening tabungan di Bank tersebut. 2) Nasabah penabung yang telah menabung lebih dari satu tahun.

Untuk memperoleh data serta keterangan yang diperoleh dalam penyusunan proposal ini, penulis menggunakan beberapa metode pengumpulan data yang relevan untuk memecahkan dan menganalisa masalah yang telah dikemukakan sebelumnya. Cara yang dilakukan sebagai berikut : 1) Observasi, 2) Dokumentasi, 3) Kuesioner.

Analisis data dilakukan dengan cara analisis kuantitatif dengan menggunakan metode Partial Least Square (PLS).

\section{HASIL PENELITIAN}

Model analisis yang dipergunakan dalam penelitian ini adalah analisis yang diperoleh dari pengaruh bauran pemasaran jasa terhadap keputusan nasabah memilih produk bank syariah pada PT.Bank Sulselbar kantor Cabang Syariah Makassrar dan diolah dengan menggunakan Partial Least Square Partial Modeling (PLS-PM).

1. Evaluasi Outer Model mendefinisikan bagaimana setiap blok indikator berhubungan dengan variabel latennya. Sebagaimana gambar C.1 dibawah ini menunjukkan indicator reflektif 
Gambar C.1 Indicator Reflektif

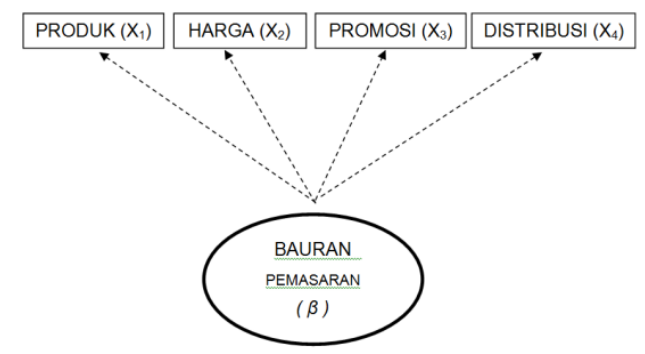

$x_{1 \beta+\varepsilon} \quad x_{2 \beta+\varepsilon} \quad x_{3 \beta+\varepsilon} \quad x_{4 \beta+\varepsilon}$

Model pengukuran atau outer model dengan indikator reflektif di evaluasi dengan Convergent dan decrimentvalidity. Untuk validitas indikator dapat dilihat dari nilai loading factor (standardized loading) nilai ini menggambarkan besarnya korelasi antara tiap indikator akan valid bila memiliki nilai standardized loading lebih dari 0,5. Berdasarkan loading factor correlation (dimension). Dan untuk Evaluasi confergent validity meliputi reliability (validitas indikator) reliability variabel dimulai Average Varibel Extrated (AVE).

Berdasarkan tabel C.1 di atas dapat dilihat bahwa nilai indikator yang memiliki korelasi dengan variabel bank adalah dimana nilai standardized loading untuk indikator

$$
\begin{aligned}
& X_{1}=0,095<0,5 \\
& X_{2}=0,549>0,5 \\
& X_{3}=0,325<0,5 \\
& X_{4}=0,867>0,5
\end{aligned}
$$

Ini menunjukkan indicator

Produk $\left(x_{1}\right)$, Harga $\left(x_{2}\right) \quad$ valid sedangkan Promosi $\left(x_{3}\right)$ tidak Valid dan Distribusi $\left(X_{4}\right)$ valid .Untuk nilai communalities $x_{1}=0,009$, tidak valid dan $x_{2}=0,301$ yang menunjukkan ketidakvalidan indicator. Adapun untuk promosi $\left(x_{3}\right)$ memiliki communalities 0,106 dan untuk distribusi $\left(X_{4}\right)$ memiliki communalities. Artinya untuk indikator $\mathrm{X}_{3}$ tidak valid indicator seb sedangkan untuk $\mathrm{X}_{4}$ memilki indikator 0.752 . Hal ini menunjukkan bahwa dari keempat indikator dapat diketahui bahwa indikator yang paling dominan dalam mempengaruhi variabel (Bauran Pemasaran) adalah $\mathrm{X}_{4}$. 
Table C.1 Correlations (Dimension 1)

\begin{tabular}{|c|c|c|c|c|c|}
\hline $\begin{array}{l}\text { Latent } \\
\text { Variable }\end{array}$ & $\begin{array}{l}\text { Manifest } \\
\text { Variables }\end{array}$ & $\begin{array}{l}\text { Standardize } \\
\text { d loading }\end{array}$ & $\begin{array}{l}\text { Loadin } \\
\text { gs }\end{array}$ & $\begin{array}{l}\text { Locatio } \\
n\end{array}$ & Comunalities \\
\hline \multirow{4}{*}{$\begin{array}{l}\text { Bauran } \\
\text { Pemasaran }\end{array}$} & Produk & 0.095 & 0.013 & 0.000 & 0.009 \\
\hline & Harga & 0.549 & 0.093 & 0.000 & 0.301 \\
\hline & Promosi & 0.325 & 0.055 & 0.000 & 0.106 \\
\hline & Distribusi & 0.867 & 0.123 & 0.000 & 0.752 \\
\hline \multirow{3}{*}{$\begin{array}{l}\text { PT.Bank } \\
\text { Sulselbar }\end{array}$} & Lokasi & 1.000 & 3.765 & 0.000 & 1.000 \\
\hline & Pelayanan & 0.996 & 0.767 & 0.000 & 0.993 \\
\hline & Nasabah & 0.998 & 0.923 & 0.000 & 0.995 \\
\hline \multirow{4}{*}{$\begin{array}{l}\text { Keputusan } \\
\text { Nasabah }\end{array}$} & Kebutuhan & 1.000 & 1.105 & 0.000 & 1.000 \\
\hline & Lingkungan & 1.000 & 1.322 & 0.000 & 1.000 \\
\hline & Pemahaman & 1.000 & 1.575 & 0.000 & 1.000 \\
\hline & Kepercayaan & 1.000 & 1.139 & 0.000 & 1.000 \\
\hline
\end{tabular}

Kemudian untuk melihat nilai indikator yang memiliki korelasi dengan variabel PT. Bank Sulselbar Syariah adalah Berdasarkan loading factor correlation (dimension) dimana nilai standardized loading adalah:

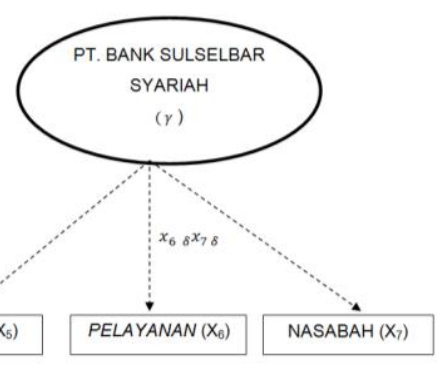

$$
\begin{array}{cl}
\text { Gambar C.2 Loading Factor } & X_{5}=1.000>0,5 \\
\text { Correlation (dimension) } & X_{6}=0,996>0,5 \\
& X_{7}=0,998>0,5
\end{array}
$$


Ini menunjukkan indikator Lokasi $\left(X_{5}\right)$, Pelayanan $\left(X_{6}\right)$, Nasabah $\left(X_{7}\right)$,ketiga indikator pada variabel PT.Bank Sulselbar Syariah valid, nilai disetiap standardized loading. Nilai communalities $X_{5}=1,000$ yang menunjukkan bahwa valid indikator $\mathrm{X}_{5}$ sehingga mampu dijelaskan dalam konstan PT.Bank Sulselbar Syariah demikian pula $X_{6}$, $\mathrm{X}_{7}$ masing-masing 0,996, 0,998 ini membuktikan dari keempat indikator $\left(X_{5}, X_{6}, X_{7}\right)$, terlihat bahwa indikator kinerja $\left(X_{5}\right)$ dan waktu $\left(X_{6}\right)$ merupakan indikator yang paling dominan dalam mempengaruhi variabel PT.Bank Sulselbar Syariah yaitu sebesar 1.000.

Kemudian untuk melihat nilai indikator yang memiliki korelasi dengan variabel Keputusan Nasabah adalah berdasarkan loading factor correlation (dimension) dimana nilai standardized loading diatas adalah:

\section{Gambar C.3 Loading Factor Correlation (Dimension):}

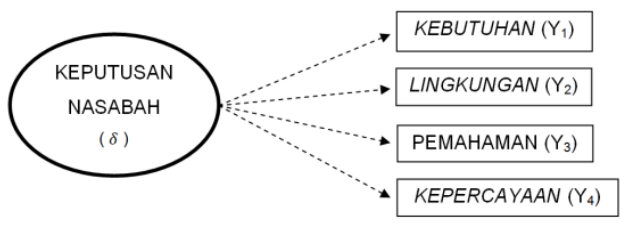

$$
\begin{aligned}
& Y_{1}=-1.000>0,5 \\
& Y_{2}=1.000>0,5 \\
& Y_{3}=1.000>0,5 \\
& \mathbf{y}_{4}=1.000>0,5 \\
& \text { Ini menunjukkan indikator }
\end{aligned}
$$
Kebutuhan $\left(\boldsymbol{Y}_{\mathbf{1}}\right)$, indicator Lingkungan $\left(\boldsymbol{Y}_{2}\right)$, dan indikator Pemahaman $\left(\boldsymbol{Y}_{\mathbf{3}}\right)$, indikator Kepercayaan (Y4) valid karena nilai kuadrat disetiap standardized loading. Nilai communalities $\left(\boldsymbol{Y}_{\mathbf{1}}\right)=1,000$ Sedangkan $\left(\boldsymbol{Y}_{2}\right),\left(\boldsymbol{Y}_{3}\right)$ dan $\left(\boldsymbol{Y}_{4}\right)$ masingmasing memilki communalities 1.000 . Ini membuktikan dari keempat indikator $\left(Y_{1}, Y_{2}, Y_{3}, Y_{4}\right)$ mempengaruhi variabel Bauran Pemasaran.

Untuk mengukur atau menguji nilai loading faktor di indikator dilihat pengukuran dari hasil Critical Ratio (CR) pengukuran ini dari hasil nilai standardized loading yang diperoleh dari bostrapping dengan standar caranya. $\mathrm{CR}=$ nilai statistik maka dapat dilihat dari loading factor Composit Reliability. 
2. Uji Reliabilitas (Konsisten Interna)

Tabel C.2 Composite Reliability

\begin{tabular}{lccc}
\hline \multicolumn{1}{c}{ Latent variable } & Dimensions & $\begin{array}{c}\text { Cronbach's } \\
\text { alpha }\end{array}$ & $\begin{array}{c}\text { D.G. rho } \\
(P C A)\end{array}$ \\
\hline $\begin{array}{l}\text { PT. Bank } \\
\text { Syariah }\end{array}$ & Sulselbar & 0,713 & 1.000 \\
\hline Bauran Pemasaran & 4 & 0.993 & 1.000 \\
\hline \multicolumn{2}{l}{ Keputusan Nasabah } & 4 & \\
\hline
\end{tabular}

Uji Model Assessment (Penilaian)

Pengujian atau pemeriksaan selanjutnya dengan melihat nilai AVE (Average Varible Extrated) yaitu menggambarkan besaran varian yang mampu dijelaskan oleh item - item dibandingkan varian yang disebabkan oleh error pengukuran. Standarnya adalah, bila nilai EVE (Average Varible Extrated) di atas 0.50 maka dapat dikatakan bahwa variabel memiliki Convergent Validity yang baik berdasarkan loading factor C.3 pada (Model Assessment). Nilai EVE untuk variabel.

Berdasarkan tabel C.3 di di bawah dapat dilihat bahwa nilai AVE (Average Varible Extrated) dari masing-masing variabel untuk PT.
Bank Sulselbar Syariah 0,996, Bauran Pemasaran 0,292, Keputusan Nasabah 1.000. Dari data tersebut terlihat bahwa terdapat dua variabel (PT.Bank Sulselbar Syariah dan Keputusan Nasabah) yang lebih besar dari 0.5 maka sifatnya convergent validity yang baik.

Pemeriksaan berikutnya adalah nilai descriminant validity dari model pengukuran reflektif ( $\gg$ ) yang dimiliki berdasarkan Cross Loading dan membandingkan antara nilai AVE dengan kuadrat korelasi antara variabel. Descriminant validity yang baik akan mampu menjelaskan varian indikatornya lebih tinggi dibandingkan dengan menjelaskan varian dari indikator variabel lainya. 


\section{J4 Jurnal Hukum Ekonomi Syariah | Vol. 1 | No. 2 | September 2017}

Tabel C.3 Model assessment (Dimension 1):

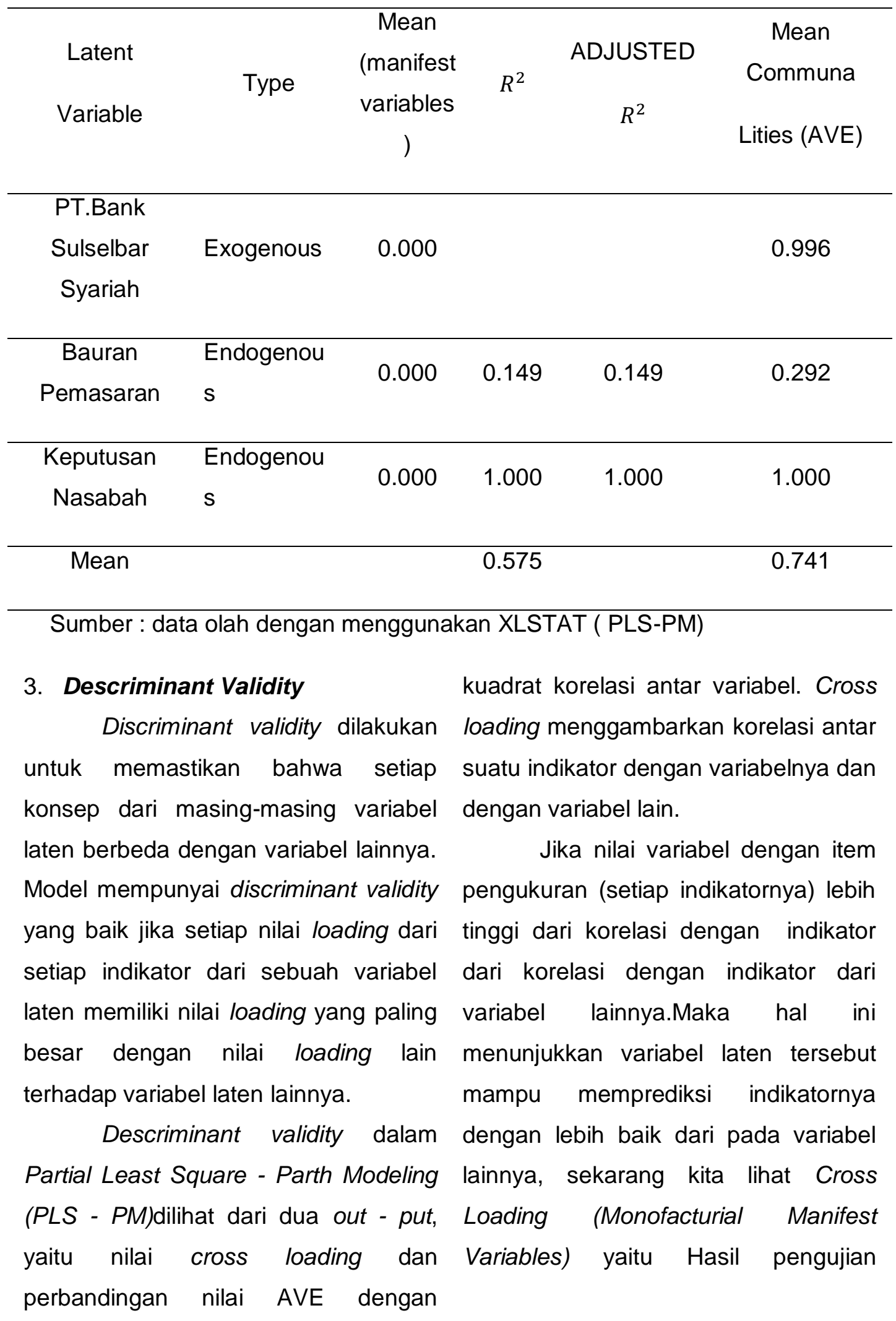


discriminant validity diperoleh sebagai berikut :
Tabel C.4 Cross-Loadings (Monofactorial Manifest Variables)

\begin{tabular}{|c|c|c|c|}
\hline & $\begin{array}{c}\text { Bauran } \\
\text { Pemasaran }\end{array}$ & $\begin{array}{c}\text { PT. Bank Sulselbar } \\
\text { Syariah }\end{array}$ & $\begin{array}{c}\text { Keputusan } \\
\text { Nasabah }\end{array}$ \\
\hline Produk & 0.095 & -0.129 & -1.105 \\
\hline Harga & 0.549 & 0.144 & 0.157 \\
\hline Promosi & 0.325 & 0.076 & 0.101 \\
\hline Distribusi & 0.867 & 0.342 & 0.372 \\
\hline Lokasi & 0.380 & 1000 & 0.999 \\
\hline Pelayanan & 0.446 & 0.996 & 0.999 \\
\hline Nasabah & 0.442 & 0.998 & 0.999 \\
\hline Kebutuhan & 0.427 & 0.998 & 1.000 \\
\hline Lingkungan & 0.420 & 0.999 & 1.000 \\
\hline Pehaman & 0.407 & 1.000 & 1.000 \\
\hline Kepercayaan & 0.425 & 0.999 & 1.000 \\
\hline
\end{tabular}

Sumber : data olah dengan menggunakan XLSTAT ( PLS-PM)

Berdasarkan tabel C.4 di atas dimana nilai standardized loading dapat dilihat bahwa nilai indikator untuk indikator $X_{1}=0,095, X_{2}=$ yang memiliki korelasi dengan 0,549, $X_{3}=0,325 . X 4=0,867$, Nilai variabel Bauran Pemasaran adalah masing-masing variabel $>0,5$ 
4. .Inner Model (Pengujian Model Struktural)

Tabel C.5 Path coefficients (Bauran Pemasaran/1)

$\mathbf{R}^{2}$ (Bauran Pemasaran / 1):

\begin{tabular}{|c|c|c|c|c|c|c|c|}
\hline$R^{2}$ & $F$ & $\mathrm{Pr}>\mathrm{F}$ & $\begin{array}{c}R^{2} \\
\text { (Bootstrap) }\end{array}$ & $\begin{array}{c}\text { Standard } \\
\text { error }\end{array}$ & $\begin{array}{c}\text { Critical } \\
\text { ratio } \\
(\mathrm{CR})\end{array}$ & $\begin{array}{c}\text { Lower bound } \\
\qquad(95 \%)\end{array}$ & $\begin{array}{c}\text { Upper bound } \\
(95 \%)\end{array}$ \\
\hline 0,149 & 11.065 & 0,001 & 0,202 & 0,083 & 1.803 & 0.040 & 0.376 \\
\hline
\end{tabular}

Path coefficients (Bauran Pemasaran / 1):

\begin{tabular}{|c|c|c|c|c|c|c|c|c|}
\hline $\begin{array}{c}\text { Latent } \\
\text { variable }\end{array}$ & Value & $\begin{array}{c}\text { Standard } \\
\text { error }\end{array}$ & $\mathrm{T}$ & $\begin{array}{c}\operatorname{Pr}> \\
|t|\end{array}$ & $f^{2}$ & Value(Bootstrap) & $\begin{array}{c}\text { Standard } \\
\text { error(Bootstrap) }\end{array}$ & $\begin{array}{c}\text { Critical ratio } \\
\text { (CR) }\end{array}$ \\
\hline PT.BANK & 0,387 & 0,116 & 3.326 & 0,001 & 0.176 & 0.390 & 0,224 & 1. 725 \\
\hline
\end{tabular}

Sumber : data olah dengan menggunakan XLSTAT (PLS-PM.

Berdasarkan tabel path dari nilai Critical Rasio (CR) 1,725

coefficients Bank dimana nilai t statistik sehingga dapat dikatakan bahwa 1.803 untuk Bauran Pemasaran $3.326<1.725$ bahwa bank secara signifikan dengan $R$ Value 0,387 bahwa dengan mempunyai pengaruh positif terhadap standar probability $0,001<0,05$ atau variabel Bauran Pemasaran.

Tabel C.6 Path coefficients (keputusan nasabah/1)

\begin{tabular}{|c|c|c|c|c|c|c|c|}
\hline \multicolumn{8}{|c|}{$\mathbf{R}^{2}($ Keputusan Nasabah / 1): } \\
\hline $\mathrm{R}^{2}$ & $\mathrm{~F}$ & $\operatorname{Pr}>\mathrm{F}$ & $\begin{array}{l}\mathrm{R}^{2}(\mathrm{Bo} \\
\text { otstra } \\
\mathrm{p})\end{array}$ & $\begin{array}{l}\text { Stand } \\
\text { ard } \\
\text { error }\end{array}$ & $\begin{array}{l}\text { Critical } \\
\text { ratio } \\
(\mathrm{CR})\end{array}$ & $\begin{array}{l}\text { Lower } \\
\text { bound } \\
(95 \%)\end{array}$ & $\begin{array}{l}\text { Upper } \\
\text { bound } \\
(95 \%)\end{array}$ \\
\hline & 80778 & & & & 2158.7 & & \\
\hline 1.000 & .762 & 0,000 & 0,999 & 0,000 & 64 & 0.998 & 1.000 \\
\hline
\end{tabular}


Path coefficients (Keputusan

Nasabah / 1):

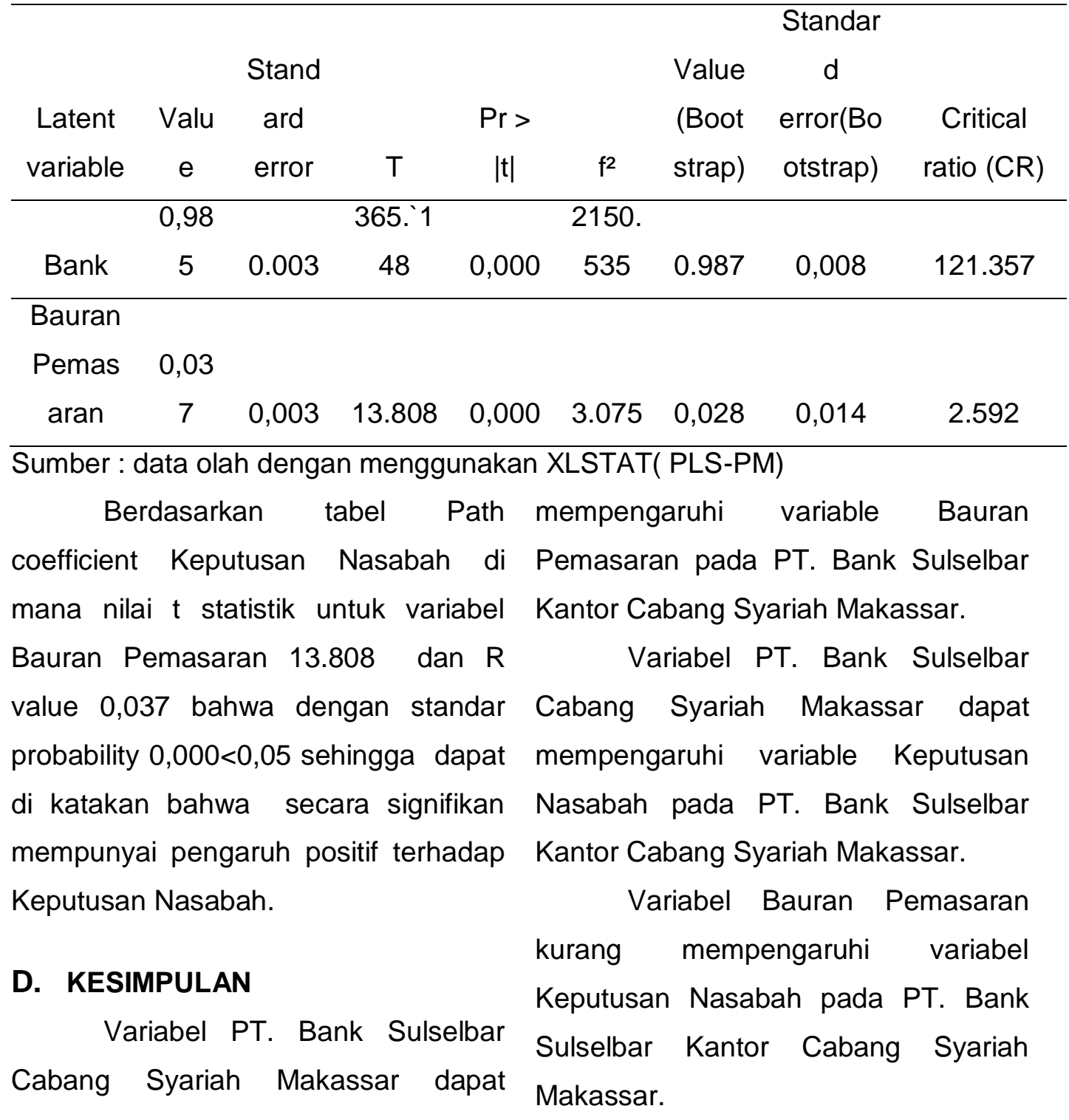

\section{DAFTAR PUSTAKA}

Alma, Buchari. 2013. Manajemen Pemasaran dan Pemasaran Jasa. Edisi Revisi. Cetakan Kesepuluh. Bandung: Alfabeta.

Amirullah. 2002. Perilaku Konsumen. Edisi Pertama. Cetakan Pertama. Jakarta: Graha IImu.

Anggen, Monica. 2012. Marketing is Terrorist. Cetakan Pertama. Jakarta: Laskar Aksara.

Departemen Agama RI. 2007. Al-qur'an dan Tarjamah. Jakarta. 
Ghozali, Imam dan Fuad. 2006. Structural Equation Modeling. Semarang: Badan Penerbit Universitas Diponegoro.

Gitosudarmo, Indrio. 2008. Manajemen Pemasaran. Edisi Kedua. Cetakan Pertama. Yogyakarta: BPFE.

Kasmir. 2004. Pemasaran Bank. Jakarta: Kencana.

Kotler, Philip. 2008. Manajemen Pemasaran. Edisi Pertama. Cetakan Ketigabelas. Jakarta: Prenhalindo.

Kotler, Philip dan Gary Armstrong. 2001. Prinsip-Prinsip Pemasaran. Edisi Kedelapan. Cetakan Pertama. Jakarta: Erlangga.

Mardani. 2014. Ayat-ayat dan Hadist Ekonomi Syariah. Edisi pertama. Cetakan Ketiga. Jakarta: Rajawali Pers.

Salusu, J. 2015. Pengambilan Keputusan Stratejik untuk Organisasi Publik dan Organisasi Nonprofit. Edisi Revisi. Cetakan Kesepuluh. Jakarta: Grasindo.

Setiadi, Nugroho J. 2003. Perilaku Konsumen Konsep Dan Implikasi untuk Strategi Dan Penelitian Pemasaran. Edisi Pertama. Cetakan Pertama. Jakatra: Kencana.

Sunyoto, Danang. 2015. Perilaku Konsumen dan Pemasaran. Cetakan Pertama. Yogyakarta: CAPS. 